\title{
SOME EARLY AUSTRALIAN MEDICAL PUBLICATIONS
}

\author{
by \\ SIR EDWARD FORD
}

ON 12 May 1787, the First Fleet of eleven ships, commanded by Captain Arthur Phillip, the Governor-elect of the new colony, sailed from England to establish a penal settlement at Botany Bay, which had been visited by Cook only eighteen years before. This was to relieve the crowded gaols and prison hulks of the convicts who, but for the recent revolt of the American colonies, would have been sent there to slave in the plantations. The fleet, with 756 convicts and 258 soldiers and marines aboard, made the long voyage of 250 days, of which about a quarter was spent in ports on the way. The settlement was founded at Port Jackson on 26 January 1788, and for some years the weakened community, beset by disease and food shortage, struggled for subsistence.

A group of some six contemporary accounts of this formative period, by officials and officers of the new colony, was published in London before the turn of the century. They have been called the incunabula of Australiana. These substantial works are all of prime importance to the medical-as well as the general history-of the period. For they give the background to medical practice, in addition to incidental references of medical interest.

SURGEON-GENERAL WHIT'S JOURNAL, 1790

The third of this notable series, A Journal of a Voyage to New South Wales, published in London in 1790, has special medical interest, for it was written by John White, R.N., Surgeon-General to the First Fleet and the new settlement. It is the earliest Australian medical work. A reprint, edited by A. H. Chisholm, was published in Sydney by Angus and Robertson, in association with the Royal Australian Historical Society, in 1962.

White's book is a handsome quarto of 300 pages, which bears a dedication to its editor, Thomas Wilson, from Sydney Cove, Port Jackson, dated 18 November 1788. It is finely illustrated with sixty-five copper engravings, hand coloured in some copies, mainly of the strange flora and fauna of the new land. The title bears a pleasing vignette of a Port Jackson scene, from a drawing by White. A long appendix contains descriptions of zoological and botanical specimens, including the kangaroo. This part of the book was undertaken by distinguished scientists (including John Hunter), working from specimens, drawings and notes sent by White.

The Journal commences on 5 March 1787, when its author joined the fleet at Plymouth, and carries on to 11 October 1788 , a period covering the voyage to Australia and the first eight or nine months of the struggling settlement. It does not give a comprehensive account of events, as is found in the books of Tench and 


\section{Sir Edward Ford}

Collins. It is rather the vivid observations of a doctor whose work takes him among all sections of the community, and an enthusiastic naturalist dropped into a new world. The book is notable, apart from its account of the voyage and the new settlement, for its descriptions of the flora and fauna, and its notes on the medicinal properties of local plants and trees.

John White (1757-1832), a naval surgeon of ten years' service, had been recommended for the post of Surgeon-General as 'a young man of much credit to his profession'. He displayed at the outset of the long voyage the competence upon which, together with that of his exceptionally able commander, Captain Phillip, the success of the expedition was to rest. When he commenced duty at Plymouth, the convicts, already embarked from insanitary prisons, had been on salt rations for four months, and were ill-nourished and unfit for the voyage. To build them up White arranged for fresh meat and vegetables to be issued for some weeks before sailing, and for the same reason the fleet anchored for a month at both Rio and the Cape of Good Hope. Special attention was given to sanitation and the provision of proper clothing, and arrangements made for regular exercise in the fresh air.

Though Phillip prepared carefully, the voyage was beset with the hazard and hardship inseparable from sea travel of the time. It was especially severe for convicts, for these were transported under conditions comparable with those of the still existing slave trade. Though scurvy and dysentery took a toll, the voyage, completed with a convict mortality of under three per cent, was of rare excellence by the standards of that time and stands in bold contrast with the mortality of about twenty-five per cent suffered on the disastrous voyage of the Second Fleet over two years later. White's Journal marks the safe arrival in Botany Bay with a note of happy relief: 'To see all the ships safe in their destined port without ever having been by accident one hour separated, and all the people in as good health as could be expected or hoped for, was a sight so truly pleasing at which every heart must rejoice'.

The Journal has formed a basis for many accounts of White's life and work in the early colony (Macpherson, 1928; Anderson, 1933; Cleland, 1950; Brown, 1951; Ford, 1954; Gandevia, 1966). The whole company landed in a weakened condition and many were carried ashore. A tented hospital was established near the western shore of Sydney Cove, which was quickly filled with scurvy and dysentery sufferers. 'More pitiable objects', White writes, 'were perhaps never seen'. For there was a shortage of medical stores and assistance, an absence of all comforts and most necessities, and an inadequate diet, for the sea ration was all that was available. Consequently the scurvy raged with increased virulence and many succumbed. Phillip was keenly aware of the need for fresh vegetables and gardens were planted, at first with poor success. The bush was searched for edible plants, but these were found only in small quantities. White and one of his assistant surgeons, Denis Considen, both naturalists, were particularly active in this work, which they combined with collecting plants and animals for study by scientists at home. Antiscorbutics were found in the local plants, but only in ineffective quantities, and consequently White reported, eight months after arrival, that 'the disorder still prevails with violence, nor can we at present find any remedy . . .

White and Considen also investigated the medicinal properties of the native flora, 


\section{Some Early Australian Medical Publications}

and obtained astringent resins from the grass-tree (Xanthorrhoea spp.) and the red mahogany ( $E$. resinifera), which were of great value in dysentery, the scourge of the settlement for many years. This interest in the resin or gum led to the eucalyptus in general being popularly known as gum-trees throughout Australia to our own time. This usage began in the earliest days of the colony and Governor Phillip, in a botanical note in a despatch of 15 May 1788, in which he laments his lack of a botanist, mentions 'the red gum taken from the large gum-tree by tapping' and speaks of the timber of gum-trees. White also distilled eucalyptus oil from the leaves of the peppermint gum, which appeared better than the English Oleum Menthae Piperitae for 'all cholicky complaints'. He sent a quart of this to England-the first local product prepared for export. At the close of his Journal, White promised a further instalment, together with 'no inconsiderable additions to the Natural History'. But though he remained in the colony for a subsequent six years, no further contribution was ever published.

White and his staff were desperately engaged for the whole of this period. The ravages of scurvy, dysentery and malnutrition continued and severe injuries were frequent. Their troubles were added to in $\mathbf{1 7 8 9}$ by a severe epidemic of smallpox, of uncertain origin, which caused heavy mortality in the aborigines of the surrounding districts. There was consternation, for smallpox, unrestricted as yet by vaccination, was one of the most dreaded of the pestilences. Despite frequent contacts, however, only one case occurred in the settlement, that of a negro seaman, who died. The next year, 1790, was disastrous, for the Second Fleet, the arrival of which with stores and fresh men was anxiously awaited, landed some 500 seriously ill convicts, in a state of disgraceful neglect. Of the 930 males who had embarked, 260 died on the voyage, 50 more within two weeks of arrival and others subsequently. This added grievously to the burden of the settlement and overwhelmed White and his slender staff.

During these 'hungry years', as they have been termed, Phillip's most pressing responsibility was to obtain enough food to keep his people alive. At times actual starvation was imminent and rations were so shortened that men fell from malnutrition, labour practically ceased and disease took heavy toll. Many were sent to Norfolk Island, where the gardens thrived, to reduce the burden. Phillip, who strictly shared the reduced general ration of the settlement, himself suffered from scurvy. His staff, including White, thoroughly hated the new land and thought it should be abandoned. But the great Governor, even in his most desperate days, retained his vision of the future, and maintained that the colony would be the most valuable acquisition that Britain ever made. White, on the contrary, cursed the place bitterly in his letters: 'a country so forbidden and hateful as only to merit execrations and curses', he wrote, 'for it has been a source of expense to the country and of evil and misfortune to us'.

In 1794 White returned to England on leave and never came back. He died in 1832. He had nurtured the medical services of this country, with notable competency and humanity, through their most desperate years.

KITE ON THE BOTANY BAY RESIN, 1795

Five years after the appearance of his Journal, White's notes on the medicinal 


\section{Sir Edward Ford}

properties of local resins were added to by Charles Kite, who devotes some fifty pages to the subject in his Essays and Observations, Physiological and Medical, on the Submersion of Animals, and on the Resin of the Acoroides Resinifera, or Yellow Resin from Botany Bay ... (London, G. Woodfall, 1795). This describes chemical and clinical tests on the astringent resin of the grass-tree (Xanthorrhoea spp.), known as Botany Bay gum. Information is included by Arthur Bowes, surgeon of the Lady Penrhyn transport of the First Fleet and others. The author concluded the gum had therapeutic value in a wide range of gastrointestinal and other ailments. It is stated that large stocks were now held by druggists, priced at $3 s .6 d$. a pound.

THOMAS JAMISON AND THE BEgINNING OF LOCAL MEDICAL PUBlications, 1804

The foundation of Australian publication was firmly laid with the arrival in Sydney of George Howe, a London trained printer, in 1800 . He came as a convict, under seven years' sentence of transportation-probably for a political offence-and was soon after made Government Printer, working in 'a ramshackle building near Government House'.

In late 1802 Howe issued the first book printed in Australia: New South Wales General Standing Orders. On 3 March of the following year (1803), he issued the first number of the first Australian newspaper, The Sydney Gazette and New South Wales Advertiser, a weekly, which survived till 20 October 1842 . As the only newspaper in the Colony for some twenty-one years, the Sydney Gazette forms an especially important historical reference to current events in the early settlement. The publication in facsimile of this rare item by the Trustees of the Public Library of New South Wales, under the terms of the Sir William Dixon Foundation, commenced with the issue of Volume 1 in 1963 and has now reached Volume 8 (to 31 December 1809).

Australian medical publication commenced in the Sydney Gazette of 14 October 1804 with a short article, 'General Observations on the Small Pox', by Thomas Jamison, M.D., the Principal Colonial Surgeon. This first locally published medical contribution appeared about five months after the introduction of vaccination to New South Wales, and contains an appeal for its general adoption, and a warning of the extreme danger of smallpox. Jenner's announcement of his discovery in 1798, about ten years after the foundation of the first settlement, had aroused the interest of the colonial medical staff and the new method had been the subject of correspondence with London. Governor King, on Jamison's advice, had requested that vaccine should be made available to the Colony, mentioning that the teats of the local cows had been unsuccessfully examined for cowpox. Vaccine, prepared by the Royal Jennerian Society, was received in Sydney in May 1804, together with a further lot addressed to Assistant Surgeon John Savage. The successful vaccination of a large number of the children was undertaken in the next few months but then, as in later days, a proportion of parents neglected their responsibilities. Jamison's paper, directed to these, is at the same time persuasive and threatening. He outlines the great advantages of vaccination, refers to the local smallpox epidemic of 1789 , and stresses the high mortality that could occur in the unprotected should it again appear.

Thomas Jamison, a Dublin graduate, arrived in Australia as surgeon's first mate in the Sirius, the flagship of the First Fleet. He was one of the naval surgeons appointed 


\section{Some Early Australian Medical Publications}

to serve as assistant surgeon in the new settlement under Principal Surgeon John White. On the early foundation of the subsidiary settlement at Norfolk Island under Lieutenant Philip Gidley King, Jamison established a hospital there and remained medical officer to the island for over ten years. He succeeded Balmain as Principal Surgeon; was involved, with subsequent disgrace, in the rebellion against Governor Bligh; and returned to England as witness in the court martial of Johnston for his part in this affair. He died there in 1811 (Macpherson, 1833; Ford, 1954).

SURGEONS AND SURGEONS-SUPERINTENDENT OF CONVICT SHIPS, 1819

Apart from the earlier accounts of the voyages of convict ships to Australia, there commenced in 1819 a series of works by surgeons or surgeons-superintendent of convict ships which extended to the mid-century. These first-hand accounts show the organization and administration of convict transportation and give intimate pictures of the daily life and routine aboard. As could be expected, they relate almost wholly to voyages in which the ability and care of the surgeon and master had resulted in a safe voyage for their charges. Less fortunate voyages, as that of the Hillsborough, which arrived in 1799 after a loss of ninety-five of the 300 prisoners embarked, usually appear only in official reports and mortality statistics. The authors are in general able and responsible, often men of ideas, anxious to display the methods they have evolved and writing about them for the information of colleagues in the service. With certain of them, such considerations are incidental to a wider narrative; in one case to an important description of life in early New South Wales.

The medical care of convicts was at first normally entrusted to surgeons engaged by the contractors, whose thoroughly unsatisfactory working conditions, pay and status were likely to appeal only to persons of poor qualifications or character. They had no official status, were entirely at the mercy of bad masters and contractors, and many drowned their troubles in drink. After the débâcle of the Second Fleet, naval surgeons were appointed to ships, as government agents, to supervise the convicts and assist the contractors' surgeon of the vessel. This led to improvements but the scheme was only partially implemented and fell into disuse.

A sweeping reform was effected after the arrival of three vessels in Sydney, in 1814, after notorious voyages in which scurvy, typhus and dysentery had thrived under conditions of flagrant neglect and incompetence. This action followed the rapid adoption of a notable Report on the Health of Transports by Assistant Surgeon William Redfern, who was appointed by Governor Macquarie to report on the epidemics on these ships and to recommend measures for preventing similar disasters. Redfern, then in charge of the General Hospital, Sydney, as both a former naval surgeon and an ex-convict, was especially qualified for this job. The master-stroke of the reform which followed was the appointment of experienced naval surgeons, as 'surgeons-superintendent' to each ship. These had over-riding powers in all matters relating to the health and welfare of the convicts, and were responsible for the hygiene of the ship, and the medical care, cleanliness, clothing, diet, and exercise of their charges, as well as their discipline and moral instruction. They were not subject to the master's orders, and acted both as official representative and surgeon of the vessel. The new system had immediate effect. The mortality rate in transit fell from 


\section{Sir Edward Ford}

about 20 per 1,000 in $1806-1814$ to about 10 per 1,000 in the following decade (Bateson, 1959), the health of convicts on arrival was vastly improved, and less trouble occurred on the voyage.

The earliest publication in the series of surgeons-superintendent is a twenty-threepage pamphlet, Convict Ships. A Narrative of a Voyage to New South Wales in the year 1816 ... (London, 1819), by John Haslam, of the transport Mariner. Its content is indicated in its extended title as describing "the nature of the accommodations, stores, diet, \&c. together with an account of the Medical Treatment and Religious Superintendence of these unfortunate persons'. Though the voyage was completed without mishap, his efforts at religious instruction and reform of his charges, which he calls his 'moral therapeutics', had failed utterly, and he despairs of the possibility of such measures having success in hardened persons of their character.

A more imposing work, Two Years in New South Wales ...., in two volumes, was published in London in 1827 by Peter Cunningham. The author had at this time made four voyages to New South Wales as surgeon-superintendent of convict ships and had resided in the colony at various times for two years. Second and third editions followed in 1827 and 1828, and three separate issues appeared in German. The book was also reissued in facsimile by the Library Board of South Australia in 1966. The extended title describes the work as 'A Series of Letters Comprising Sketches of the Actual State of Society in that Colony; of its Peculiar Advantages to Emigrants; of its Topography, Natural History, \&c, \&c'. The work gives a broad survey of the colony and its scattered settlements, through which the author travelled widely. He writes as a well-informed observer and a man of understanding and humour, interested in every aspect of the place. His lively narrative, full of anecdote and information, vividly describes the people and their daily life and occupations, as well as such features as the institutions, economy, trade and prospects of the colony. He writes for English readers, with special reference to prospective immigrants, for whom helpful advice is provided. In this he fully identifies himself with the colonials and the colony, which was, in his opinion, 'destined perhaps to become the seat of a powerful empire'.

In discussing health, Cunningham writes that ague, remittent fever (nor indeed any fever but the rum fever), did not then occur in the colony, "while measles, hooping cough, small-pox and all your similar European pests, are alike strangers to our soil'. To this list he elsewhere adds scarlet fever, intermittent fever, and typhus. Dysentery was the most prevalent and fatal disease, though rarely lethal except in "the imprudent and intemperate'. He notes the incidence of dropsy in the debauched, round worms in children, phthisis in adolescents, ophthalmia ('the blight') which occurred in summer, and an epidemic of influenza. 'True syphilis in whites', he had heard, was unknown, though gonorrhoea was common and very virulent. The 'extraordinary healthiness of the climate', he observes, 'must be of no trifling importance in the eyes of a European, considering how unhealthy most new countries are'.

Cunningham's description of convict transportation and its problems, of which he presents a vivid picture, and his own methods of dealing with these, display humanity and common sense, as well as knowledge of his fellow humans. Apart from the general hygiene and disciplinary responsibilities of a surgeon-superintendent he names, as 


\section{Some Early Australian Medical Publications}

the main measures for the health and welfare of his charges: 'promoting cleanliness, comfort and hilarity among them; admitting them freely upon deck to take the air; and striking off their irons as early as ... due caution may warrant'. Their time was occupied with work and with entertainments-concerts, singing and dancing-to keep up their spirits. He held enlightened views on punishment and considered that this should be certain rather than severe. Since flogging debased and brutalised, he preferred a regimen of bread and water for offenders in the rampant thieving that existed. He believed it was fruitless to attempt moral reform through religion in this environment and impressed on them, rather, that it would be of future benefit to them if they amended their ways.

There were special problems in the transport of women on account of their profligacy and temperament. In former days, when female convicts freely consorted with seamen during the voyage, less trouble was encountered. He regarded it as a paradox that this wickedness benefited the reformation of the women 'when the rules of decency were not outraged', which he ascribes as due to their introduction to 'the moral principle of personal attachment, unknown to them before'. The present official orders in regard to segregation were cunningly circumvented, and he considered that a surgeon who endeavoured to strictly enforce them should be 'most justly entitled to the full honour of Catholic canonization on his landing'.

The ability and high standards, which are indicated in his book, are proved by a proud note in its preface that in the author's four voyages, over 600 convicts had been carried without a single death.

Following this masterpiece, Cunningham produced two further books. The first of these, which appeared in 1834, was a treatise On the Motions of the Earth and Heavenly Bodies, as explainable by electro-magnetic attraction and repulsion, and on the Conception, Growth, and Decay of Man, and Cause and Treatment of his Diseases, as referable to Galvanic Action (London, Cochrane \& McCrone). The other, with the title of Hints for Australian Emigrants (London, Boone, 1841), consists, apart from a chapter on diet, of information on agriculture and husbandry.

Another naval surgeon of comparable ability and experience, Colin Arrott Browning, M.D., a humane and devout man who devoted himself to the reform and education of convicts with evangelical fervour, published a number of works. He served as surgeon-superintendent nine times between 1831 and 1848, with interposed service on ships of war. His first publication, An Address to Prisoners . . . (Hobart Town, James Ross, 1836) was a farewell sermon of religious and moral exhortation, delivered to his charges on disembarkation. Two similar minor works followed: An Address to Women . . . (Sydney, James Tegg, 1841), for female convicts, and $A$ Brief Word of Advice to the Men . . . (Hobart Town, James Barnard, Government Printer, 1843). The first of his two major contributions, England's Exiles; or, a View of a System of Instruction and Discipline ... (London, Darton \& Clark) was published in 1842. This was followed by a book of similar content, The Convict Ship: A Narrative of the Results of Scriptural Instruction and Moral Discipline . . . (London, Smith Elder) in 1844. Second editions of these were published, with modifications, in a combined volume, The Convict Ship, and England's Exiles (1847), which ran to a fifth English and two American editions. 


\section{Sir Edward Ford}

Practically the whole of these works is concerned with an organized system of educational, moral and religious instruction developed by the author for the reform of convicts and pursued with tremendous dedication and labour. This was supported by the official instructions which required surgeons-superintendent 'to promote a religious and moral disposition' in the convicts. Only five of his 414 pages are devoted specifically to health. This work was reviewed by Verso (1950) and Gandevia (1966), the latter comparing Browning's procedures with those of Cunningham.

From their embarkation, which was marked by a long moral address, to the end of the voyage, similarly treated, Browning's prisoners were fully occupied by a routine of work, schools and lectures, and devotional sessions. They were divided into small classes, according to literacy, each under a convict teacher, for reading and writing, moral and scriptural instruction, and useful information, occupying some three and a half hours a day. Individual records were kept, periodic examinations held, and an end-voyage prize-giving - chiefly of 'copies of the sacred Scriptures'-were held. Punishment was mild, since 'reform needs merciful laws', and flogging, though authorized, was regarded as unnecessary, and evidence of unfitness to command. Since all irons were removed on joining the ship, reapplication of these, or confinement, were the main punishments. Minor offences were judged by a convict tribunal. In fact, convicts were treated as human beings. In the 'moral and spiritual atmosphere' which Browning sought, however, there was no place for Cunningham's dancing and singing and frolic, though 'the singing of psalms, hymns and spiritual songs' was encouraged. He notes that on the voyage 'not only were no lashes inflicted, but not an iron was used, nor a convict placed under a sentry'.

This change from prison brutality to an atmosphere of lessened restraint and kindly treatment was obviously beneficial to the health and content of the prisoners. High claims were also made in regard to their moral and religious regeneration, the aim of his constant routine of warning and exhortation in the revivalist tradition, which may well have been overestimated. But whatever the ultimate effect on morals, this ardent reformer taught hundreds of new Australians to read and write and landed them safely and in good health.

A further short contribution (twenty-five pages), of which the main theme is the education of convicts in transit, was published at Devonport under the title of Scraps and Facts of Convict Ships by a Scottish graduate, Andrew Henderson, M.D., F.R.C.P.E., in 1845. The author, a dour, able doctor, made nine voyages as surgeonsuperintendent of convict ships between 1829 and 1842 . He bore an excellent record, with ten deaths occurring in over 1750 convicts under his charge (Bateson, 1959). In addition to his obviously excellent medical care, he organized schools, of which 'education and behaviour lists' are 'printed to show younger men in the service what has been done for convicts during a voyage ... R Remarks from the records of the Hindostan, in which 200 boys were in 1840 transported on a non-stop voyage to Van Diemen's Land without serious illness, are included. This is referred to in his rather truculent correspondence with the Admiralty on an obstinately held view, supported by inconclusive evidence, that lemon juice, then issued to the transports, was ineffective in preventing scurvy. A courteous reply from their Lordships indicates the esteem in which he was regarded. 


\title{
Some Early Australian Medical Publications
}

Works additional to those cited, by stalwarts of this honoured service, include Narrative of a Voyage Round the World; Comprehending an Account of the Wreck of the Ship 'Governor Ready', in Torres Straits . . . (London, Sherwood, Gilbert, Piper, 1835), by T. B. Wilson, M.D. This contains accounts of the settlements at Melville Island and Raffles Bay, Northern Australia, with notes on health, aborigines and suitability of the country for white occupation.

HENRY JEANNERET AND THE FIRST AUSTRALIAN WORK ON DENTISTRY, 1830

The first Australian dental publication, Hints for the Preservation of the Teeth, by Henry Jeanneret, M.D., was printed in Sydney by R. Mansfield in 1830 . On its title the author is described as 'Surgeon \& Dentist'. It was written for the public, and is distinguished as a learned and useful contribution to its subject. This work, an octavo pamphlet of thirty-four pages, is exceedingly rare, Ferguson's Bibliography listing a single copy, which is in the Mitchell Library. It contains chapters on teething and the shedding of the teeth; preservation of the teeth: diseases of the teeth; decay (and its repair: by cavity filling with gold or mineral cement, filling, excision, extraction); toothache; irregularity and looseness of the teeth; diseases of the gums; and artificial teeth and palates. Apart from its outmoded pathology, a surprisingly 'presentday' impression is conveyed by the work. This arises from the author's insistence on high technical standards and conservative methods. His outlook on extractions is firmly and repeatedly stated:

\begin{abstract}
When we consider the multitudes, who impatient of a few transient moments of pain, insist upon the extraction of their teeth, and when we witness the needless readiness with which many persons undertake to perform this operation, we must cease to wonder at the comparatively small number of persons, who at an advanced age, retain any reasonable portion of these organs. Were dentists to boast of the number of teeth which by their skill have been rendered firm, and painless, and useful to their patients, instead of representing and magnifying the facility with which they extract those which are the most firmly attached, and that perhaps with comparatively little pain, regardless of the miserable deformity and weakened power they have occasioned, they would be better entitled to the merit they demand.
\end{abstract}

A recent dental writer (Levine, 1967), in a critical appreciation of the work, comments on Jeanneret's conservative and ethical approach to dental practice and concludes that 'it is a great pity that he did not stay in Sydney where he might have exerted a great influence upon dentistry in this country'.

For Henry Jeanneret Australia was a land of disappointment. He came here in 1829 in the hope of obtaining a grant of land, which he claimed was promised by the Colonial Office. He failed in this, and for the following twenty-five years, at least, engaged in constant and rebuffed appeals to the authorities. Jeanneret practised medicine and dentistry in Sydney until 1840, and was subsequently Superintendent of Aborigines in Van Diemen's Land. He returned to England in 1851 after a disastrously troubled ten years of service. Here he published a pamphlet of thirty-four pages on Epidemic Cholera Diarrhoea and Dysentery. Pointing out an Effectual and Expeditious Method of Cure ... (London, 1857). In this he extols the value of camphor in the treatment of cholera, with notes of its use by him in the English epidemic of 1854, and references to his Australian experience of acute bowel diseases. A further contribution of eleven pages on the same subject appeared later in French: De la 


\section{Sir Edward Ford}

guérison prompte et facile du choléra asiatique . . . (Cheltenham, 1865). He also, in his The Vindication of a Colonial Magistrate from the Aspersions of His Grace the Duke of Newcastle . . . (pp. 66, London, 1854), violently attacks Newcastle, the Colonial Secretary, whom he blames, perhaps rightly, for the official 'persecution' of his colonial days (Ford, 1952).

GEORGE BENNETT's Wanderings in New South Wales . . ., 1834

In 1834 a notable work was published in London by a young surgeon, George Bennett (1804-1893), F.R.C.S., who was to become a distinguished Sydney practitioner and the greatest of Australian doctor-naturalists. Before commencing his medical training he spent two years abroad, visiting Ceylon and Mauritius. On qualifying M.R.C.S. in 1828, he joined a scientific expedition as surgeon-naturalist and visited Sydney and New Zealand in 1829, and for the next year sailed among the Polynesian Islands and New Hebrides. Here he was the first to collect a live specimen of the pearly nautilus. He published many papers on the botany and zoology of the islands visited and as a result, was distinguished by election as Fellow of the Linnean Society and Corresponding Member of the Zoological Society.

Within a year of his homecoming, Bennett set out again for this 'comparatively new and extraordinary portion of the globe'. His travels are described in the two volumes of his Wanderings in New South Wales, Batavia, Pedir Coast, Singapore, and China; being the Journal of a Naturalist in Those Countries, during 1832, 1833, and 1834 (London, Richard Bentley, 1834). His well-written narrative is vivid and fresh, and its excellent records of the flora and fauna encountered are presented with youthful enthusiasm. On the voyage round the Cape, he studied the luminosity of the ocean, the albatross, the flight of flying fish, and Physalia (the Portuguese man of war), including the method and effects of its sting, on which he conducted personal experiments. All of these formed subjects for later scientific papers.

Bennett landed in Sydney in August 1832 and spent seven months in the colony. Sydney, then a town of 16,000 inhabitants of whom nearly 3,000 were convicts, had improved and enlarged since his previous visit in 1829 and he writes with enthusiasm of its growing prosperity. Food was abundant and cheap, with beef one penny a pound and fruit and vegetables plentiful. The poorly built wooden houses were being replaced by more substantial structures, and many had flower and vegetable gardens. Rents were very high; streets were dusty and often out of repair; and shops of various kinds were numerous. Every house, he says, had its caged parrot, screeching, babbling and whistling: "it is the street music of the colony, and "pretty polly", "sweet polly" are tender sounds which issue from . . . every dwelling'. It was spring and the surroundings of the town had 'a gay and brilliant aspect from the profusion of flowering shrubs and plants ... . He was plainly impressed by the wealth of the colony and enchanted by its largely untrodden fields of natural history. He urges that, on account of its importance, it should be abandoned as a penal settlement and full immigration encouraged.

Though devoted mainly to natural history, the book is scattered with medical observations. It is observed that though the climate was healthy and local diseases few, much illness occurred in Sydney, though less inland, from 'dissipation and 


\section{Some Early Australian Medical Publications}

introduced vice'. Intemperance was rife and was a prime cause of increased mortality. The medicinal properties of plants and trees, snakebite and ophthalmia are among the subjects noted and his observations on aboriginal manners and customs include native medicine, midwifery and infanticide. His discovery of scars resembling those of smallpox in aborigines on the Goulburn plains led to his making local and official enquiries into an epidemic which was the second since the foundation of the colony and the first in which Europeans were involved. He devotes a chapter to this (reprinted by Cumpston, 1914), in which the clinical features and native attempts at treatment are described. In this he includes much information from a report provided by Dr. Mair, assistant surgeon of the 39th Regiment, who had been sent by the Government to investigate the epidemic, According to Cleland (1950), this is apparently the only record available of the content of this report.

After a short stay in Sydney Bennett undertook a long journey of about six weeks into the interior. His object was to extend his scientific investigations and particularly, though it is not stated in the book, to study the method of generation of the kangaroo and the living habits and procreation of the platypus. He had discussed these with Richard Owen (later Sir Richard, F.R.S.), a life-long friend, of the Royal College of Surgeons of England. Owen, the foremost British comparative anatomist of his time, later became Curator of the Hunterian Museum and first Hunterian Professor of Comparative Anatomy and Physiology of the Royal College of Surgeons. Bennett set out on horseback, crossing the Blue Mountains, where a large chain gang was still working on the road, and thence to the Goulburn plains, returning to Sydney, over Razorback Mountain and through Mittagong and Liverpool. He gives a detailed account of this strenuous journey, with lively pictures of the country, and constant observations of scientific interest of the aborigines and the fauna and flora. Many of the latter were subjects of subsequent scientific papers. Writing of convict servants he notes that London pick-pockets are considered to make the best shepherds in the colony, as it suits their naturally lazy habits; the industrious labourer cannot endure the wearisome and lazy employment of looking after sheep. He observes that in the settled parts of the colony 'the harmless kangaroos and emus are rarely seen' and regrets 'that human beings are so eager to destroy, even to extermination . . . animals found in a new country'.

In a wide range of animals described in the book, the platypus, which aroused more interest among European scientists than any other animal, is scarcely mentioned. But though unrecorded in his narrative, during this journey he studied the habits of the platypus and secured specimens, with aboriginal help, about the Murrumbidgee River. A female taken alive, which he dug from a burrow, was the first live specimen ever to be obtained by a European and her burrow the first one described. Bennett at once left for Sydney, with his prize in a box on his horse, allowing it to swim and feed in streams on the way, tethered by a long line to its leg. Near Mittagong, however, it escaped, to his extreme disappointment.

To retrieve this loss, Bennett set out on a second tour without delay, crossing the Razorback Mountain to Yass and the Goulburn plains and thence to Tumut, where he describes the swarming of the Bogong moth, an annual feast of the aborigines. He secured a number of platypus specimens and returned to Sydney with a live grown 


\section{Sir Edward Ford}

female and two young. The adult died but the young ones reached Sydney safely, where he kept them in his room, in which they fed and played. They died in about five weeks, the first of his long series of failed attempts at platypus domestication. Bennett sent many specimens, sketches and notes to Owen.

Bennett left Sydney for England, on a voyage of over a year, early in 1833 . He visited various parts of Asia, the account of which fills the second volume of his book. During his stay in England he was awarded the rarely bestowed Gold Medal of the Royal College of Surgeons for his contributions to biological science, and delivered a series of papers at the Zoological Society. Among these was his 'Notes on the Natural History and Habits of Ornithorhynchus Paradoxus', the most detailed early work on this subject, which appeared later in the Society's Transactions. It is evident that his suppression of notes on the platypus in his book was to ensure priority for its scientific publication.

In less than a year, Bennett sailed again for Sydney, where he remained for the rest of his life. He practised medicine and maintained his scientific interests, was a leader in the development of the Australian Museum and in the Zoological and Acclimatization Societies, an examiner of the Faculty of Medicine of Sydney University, and a notable collector of scientific books. His work is described by Cleland (1950) and Coppleson (1955).

In 1860 Bennett published Gatherings of a Naturalist in Australasia: being Observations Principally on the Animal and Vegetable Productions of New South Wales, New Zealand, and some of the Austral Islands (London, Jan Van Voorst, 1860), illustrated with hand-coloured lithographs from drawings by the author. This fine volume has the excellent characteristics of his earlier work.

\section{DOCTORS DIFFER, 1838}

Prior to the rise of the medical societies and medical journals, items of a highly professional character were commonly reported in the public press-a practice of modern revival. Medical disputes were also aired, frequently with vehemence, in the press or by pamphlet. Two of the earliest examples of the latter are noted.

In 1838 James Mitchell, Colonial Surgeon in charge of the General Hospital, Sydney, published his defence against charges of disobedience to orders for which he had been dismissed from the service. This is a book of 160 pages (including 108 pages of appendix) and a plan of the Hospital, entitled Statement of the Case of Jas Mitchell, Esq. Late Surgeon on the Civil Establishment of New South Wales (Sydney, Herald Office). The charges followed dissension with the Deputy Director General of Hospitals, John Vaughan Thompson, whose tactless administration had led to wide dissatisfaction. Mitchell opposed his procedures and was dismissed for refusing to obey his order to superintend the flogging of prisoners, an abhorrent task that had been the duty of his assistant surgeon for many years. After his dismissal Mitchell engaged in private practice and various business interests, and acquired coal-bearing land in the Hunter River district, from which he established a fortune. He was the father of David Scott Mitchell, founder of the Mitchell Library. His case is discussed (with biography) by A. M. McIntosh (1956).

In 1846 Farquhar M'Crae, honorary surgeon to the Sydney Infirmary, in a letter 


\section{Some Early Australian Medical Publications}

to Sydney Morning Herald, complained that William Bland, after seeing a patient with him in consultation, had informed her husband that M'Crae's treatment was harmful and endangered her life. Bland denied this in the same paper and a vehement correspondence ensued. Thereafter each republished the correspondence, with his own comments. M'Crae's fifteen-page pamphlet, Correspondence between Dr. Farquhar M'Crae and Mr. Surgeon Bland (Sydney, Kemp \& Fairfax), was replied to with one of similar title of forty-two pages (Sydney, James Reading). A later adjudicator considered that while honours were about equal, neither the parties nor the profession gained in prestige (McIntosh, 1951).

ROBERT PORTER WELCH ON DISEASES OF THE EYE, 1840

A pamphlet of twenty-four pages, $A$ Familiar Treatise on Diseases of the Eye, by Robert Porter Welch, M.R.C.S., which was published in Sydney in 1840, was the first Australian ophthalmological contribution. It was printed by T. Trood, and appeared in green paper wrappers bearing a repetition of the title. A single copy, in the Mitchell Library, is the only example of which a record has been found. Such rarity accompanies most Australian printings before 1850 . For, as mentioned by Sir John Ferguson, the numbers of these issued were probably very limited and also, since they were mostly for current use, they were likely to be discarded when their immediate value ended.

Its author, who had arrived in Australia the previous year, combined medical practice with a pharmacy business in King Street, Sydney. He is described on the title as 'Late One of the Surgeons of the Taunton and Somerset Hospital and Author of "The Married Woman's Adviser and Young Mother's Guide".'

The treatise was written for family rather than professional use, and contains an account which largely omits discussion of conditions for which professional care was considered necessary, mentioning the point at which this should be sought. The Australian climate impresses the author as especially conducive to eye affections on account of the intense sun-glare, hot winds, dust and, not infrequently, constitutions 'rendered inflammatory by climate or intemperance'. He recommends protective spectacles and black or green veils as routine summer wear for ladies, which could also be worn by men 'without the imputation of effeminacy'. Special emphasis is given to acute and chronic inflammatory conditions of the eye and it is noted that 'every disease that attacks the Eye in this country is considered to be well explained under the comprehensive term, "blight".' Corneal ulceration, trauma and foreign bodies are considered, with some discussion of defects of vision.

No existing copy of The Married Woman's Adviser and Young Mother's Guide, noted on the title of the Treatise, has been traced. A notice on the back wrapper of the latter mentions the book as 'recently published' and quotes an extract from the Paris and London Advertiser stating that 'this little book is what it professes to beno lady's medicine chest is complete without it'. It appears that this work was published shortly before Welch left England.

In 1841, the year after the issue of his pamphlet on diseases of the eye, Welch published a book of verses under the title of Songs, Ballads and Rhymes (Sydney, T. Trood). It is an octavo of eighty-six pages. Two issues appeared in the same year, 


\section{Sir Edward Ford}

the only variation in these being that, in one, probably the earlier, the title bears the initials of its author (R.P.W.), while the other carries his full name. A preface states that the composition of the poems 'served, on my voyage to the shores of Australia, to beguile many of the weary hours that must be experienced in a journey of four months'. While the book is notable in that few separate collections of verse were published in Australia at an earlier time, its contents are not distinguished by poetical merit, and present-day readers will agree with Miller (1940) that, like other poetry books of its decade, it is now merely of historical and bibliographical interest.

Welch appears to have left Sydney about 1844, up to which time his name appeared frequently in business and political notices in the local press. In 1847 he published a thirty-page pamphlet in London, Observations on Convict and Free Labour for New South Wales (Simmonds \& Ward), a reprint from the Colonial Magazine of that year.

WILLIAM BLAND ON SCARLATINA, 1841

The earliest contribution to clinical medicine published in Australia appeared in 1841, under the title of Paper on the Present Epidemic Scarlatina, Read to Some Professional Friends. It is an octavo pamphlet of thirteen pages in green paper wrappers, printed in Sydney by James Tegg \& Co. The author was William Bland (1789-1868), formerly Surgeon, R.N., who had been convicted and transported for seven years for killing a fellow-officer in a pistol duel. He was the first doctor to engage in full-time general practice in Australia, and attained eminence, both in the medical profession and as a leader in the long and determined political struggles for constitutional government in the colony. An excellent account of his life and work is provided by McIntosh (1954).

Bland's scarlatina pamphlet is exceedingly rare, only two copies being known. In it the author states that 'The present Epidemic is the first instance of Scarlatina in any form in the Colony, at least as an Epidemic, and infinitely the most frightful in its effects, and the most fatal, if not the most widespread disease with which it has ever been visited'. He discusses the clinical features and treatment of the disease.

William Bland's extensive bibliography commences in 1831 , when he appears as editor of the locally published A Journey of Discovery to Port Phillip by his friends, the explorers W. H. Hovell and Hamilton Hume. Then follows the first of a long series of political works, which are important in the record of the battle for constitutional government. This was largely won through the action of the Australian Patriotic Association, of which Sir John Jamison, a former naval surgeon and W. C. Wentworth, both sons of principal surgeons of the colony, served as President and Vice-President, and Bland as Secretary. The Association was founded in 1835 to bring the views of the colonists before the House of Commons, where the local situation was only vaguely understood. Bland was responsible for voluminous and critical correspondence with London, parts of which appear in his publications. In the first election for the newly established Legislative Council in 1843, Wentworth and Bland topped the polls for Sydney. Bland lost his seat at the next election through his support of an unpopular measure. But in 1856, when the introduction of full representative government crowned his labours, he was appointed to the Legislative Council, where he held office till his retirement from political life in 1861. 


\section{Some Early Australian Medical Publications}

In 1843, following a series of destructive fires in the cargo of ships carrying wool, which were ascribed to spontaneous combustion, Bland published and demonstrated a method he had devised for extinguishing such fires by the use of carbon dioxide. This consisted of stowing barrels of marble chips among the cargo, which were connected with the deck by pipes. On an outbreak of fire in the hold, hydrochloric acid could be poured down the pipes, which would generate the gas and so put out the fire. This appeared in 1843 in a sixteen-page pamphlet with two plates, with the title: Suppression of Spontaneous Combustion in Wool Ships, with further editions in 1845 and 1867. A model of the scheme was shown in 1851 at the International Exhibition in London. The method was said to have been used later to combat fires in mines.

Bland displayed an interest in aerial navigation which was unique in its place and time. This resulted in the invention of an airship, which he called an atmotic ship, and his publication of the first Australian contributions to aeronautics. According to his own account, his invention was produced and experimentally demonstrated as early as 1839 , and published soon after. His design, for which engineering advice was obtained, was constantly revised and a model and plans were shown in London at the Crystal Palace Exhibition in 1854 and at the Paris International Exhibition in 1855. It was sent to England for registration as a patent in 1851 . Two publications on the airship are recorded by Ferguson, both unique copies. The first of these, Seven Views of the Atmotic Ship . . . Invented by William Bland, March 10th 1851, printed in Sydney, includes title, one page of description, and seven hand-coloured lithograph plates showing plans. The other, Atmotic Ship. Invented by W. Bland (Sydney, 1855), of five pages, has four plates. Bland's design was of an elongated, hydrogen filled balloon, ninety feet long, with a suspended cabin. In general appearance it resembled a zeppelin. It was suggested that propulsion could be by sail and steam, and this was obviously the drawback of the scheme. Bland's plans for an airship, so long before its day, may be considered to have been of the nature of a Jules Verne fantasy. But he was obviously sincere in his regard for its possibility. He urged advantages not otherwise obtainable-increased speed of travel, rapid postal service, conveyance of passengers, the exploration of places inaccessible or difficult of access, aid to meteorology, and a general advantage to science and commerce. Later he even considered the possibility, by this means, of invasion by an enemy-a question of which he writes 'I must confess I have never heard raised'. His advocacy, which included approaches to Queen Victoria, the French Emperor and President Lincoln, was maintained till the time of his death.

In 1857 Bland published a thirty-two page pamphlet, Sanitary Reform of Towns and Cities (Sydney, J. Cox \& Co.), in which he discusses a public health scheme for Sydney improvement, including drainage, harbour pollution, parks and public baths.

The final item of his bibliography, published posthumously in 1892 from a manuscript 'drawn up for posterity', is Account of the duel between William Bland \& Robert Case (Sydney, Angus \& Robertson), which includes a report of his trial in 1813. This was, of course, the reason for him gracing this country.

ROBERT LITTLE ON SCARLET FEVER, 1842

In the year following the appearance of Bland's paper on scarlet fever, a further 


\section{Sir Edward Ford}

contribution on the subject, induced by the same severe local epidemic, was published in Sydney. This was a pamphlet of thirty-five pages, Practical Observations on the treatment of the Epidemic Scarlet-Fever, recently so prevalent and fatal in New South Wales (Sydney, James Tegg, 1842), by Robert Little, M.D. The author, noted on the title as late Professor of Midwifery and the Diseases of Females and Children in the Royal Belfast College and Physician to various Belfast institutions, was then practising in Hunter Street, Sydney. The Dixon Library copy is unique.

It is stated that the colony had been free from epidemic fevers till the great mortality of the past few months. These could be expected to increase as overseas communication grew. Prevention was by isolation, free ventilation, and cleanliness. The treatment is exhaustively discussed.

WILLIAM SHERWIN, FIRST OF THE NATIVE-BORN MEDICAL AUTHORS

The first medical publication by a native-born Australian, William Sherwin, M.R.C.S., appeared in Sydney in 1844. It is a pamphlet of eight pages explaining the changes which occur in the foetal circulation at birth. This bears the title of On the Primum Mobile of the Blood to the Lungs at Birth; its Complete Vitalization or Animalization; and its Subsequent Circulation, and was printed in Sydney by James Reading. The Mitchell Library copy is the only one of which a record has been found.

William Sherwin (1804-1874), who was born at Parramatta, commenced his medical training in Sydney as apprentice to William Bland at the age of thirteen, and completed his studies in England, where he qualified M.R.C.S. After returning to Sydney in 1827, he served for a year as assistant surgeon to the ill-fated Melville Island settlement in Northern Australia, where he replaced the medical officer, Dr. Gold, who had been killed by natives. In 1829 he established the first wholly private practice in Parramatta, and remained there till 1840, when he moved to Sydney (Brown, 1951). In 1862 he visited England and qualified F.R.C.S., and after his return advocated and practised homoeopathy, which antagonized some of his colleagues. In 1863 the adoption of his new creed was introduced by the publication of two lectures he had delivered on homoeopathy: Physiology and Pharmacodynamics; and Evidences of the Benefits of Homoeopathy, and Statistics of Its Success. These were pamphlets of twenty-six and twenty-five pages respectively, printed at Sydney by Hanson and Bennett. It was reported (obituary, 1874) that he had published in London a Report on Catarrh in Sheep, prepared for Governor Bourke, of which no local copy is known.

WILLIAM RUSS PUGH AND HIS CASE OF STRANGULATED HERNIA, 1845

Launceston was the scene of bitter controversy, which is described in A Letter to the Medical Profession of Van Diemen's Land: Accompanied by The Particulars of an Operation for Strangulated Congenital Hernia (Launceston, Launceston Examiner, 1845), by William Russ Pugh, an able surgeon and a pioneer of anaesthesia in Australia (Craig, 1941; Crowther, 1947). This rare pamphlet of seventy pages fully discusses the case history of a patient who was operated on for strangulated inguinal hernia by the author in 1841. His subsequent death became the subject of criticism 


\section{Some Early Australian Medical Publications}

by a local medical faction, which was joined by a young Dr. Haygarth on his arrival in the colony some months after the event. As a result of information laid by him, Pugh was charged at the police court with 'gross negligence, ignorance and rashness'. The case was dismissed, whereupon Pugh sued Haygarth and was awarded $£ 250$ damages. Haygarth, unable to pay, was imprisoned in the Hobart Town gaol for twelve months. The pamphlet includes discussion of the general and operative treatment and pathology of the case. It may be considered the earliest separate Australian publication on a surgical subject.

\section{THE AUSTRALIAN MEDICAL JOURNAL, 1846}

The earliest locally published medical journal, The Australian Medical Journal, was issued in Sydney on 1 August 1846, and ceased publication, after fifteen monthly numbers, on 1 October 1847. The first four of its sixteen-page issues were edited by George Brook, Senior Colonial Surgeon of New South Wales. On his relinquishment of the post through illness, the remaining numbers were edited by Isaac Aaron, one of the first surgeons appointed to the Sydney Infirmary and Dispensary. The printer, William Baker, of the Hibernian Press, was also proprietor, until Brook assumed ownership.

A preliminary announcement states that the journal would contain 'treatises on diseases of the Colony, intelligence selected from recent publications, and information of every kind useful to the profession'. It also states that 'a Thousand Copies of the first number in new form will be dispersed gratuitously'. This reference to a 'new form', which is repeated elsewhere, suggested to Dunlop (1927) and others that the new publication may have replaced an earlier, unknown journal. It is apparent, however, from mention by the printer of the use of 'elegant and varied type, entirely new', and of machine printing, that this relates to a new form of printing introduced at the press.

Two notable subjects appeared in the Journal in its brief life of fifteen months. The first was an announcement of the establishment in Melbourne of the Port Phillip Medical Association, the first Australian medical society, in 1846, with a first appearance in print of its rules, regulations and table of fees. The other was the rousing news of the introduction of ether anaesthesia to Australia, about eight months after it was first used by Morton in Boston, Massachusetts. This was achieved by William Russ Pugh, M.D., who operated on two patients to whom he had administered ether, at St. John's Hospital, Launceston, on 7 June 1847. He was closely followed by others in Hobart, Sydney and Melbourne, and the new method rapidly came into wide use.

The Journal's first mention of anaesthesia, induced by the glowing newspaper accounts of its overseas use, appeared on 1 June 1847, just prior to Dr. Pugh's initial use of ether. Dr. Aarons, in his editorial, 'Painless Operations', warns of the hasty adoption of a method of which the probably dangerous side effects were still unknown. He states, in conclusion: 'We have no hesitation in predicting a transient popularity; it will have its day, ultimately to be abandoned'.

In the following issue of 1 July 1847, the editor, in a leader 'Painless Surgery', modifies this extreme view and stresses that the method should be investigated 'coolly and philosophically', so that it should not be discredited by abuse. In this 
number Dr. Pugh, who had recorded a number of his surgical cases in previous issues, describes his two initial operations under ether, already reported in The Launceston Examiner, together with an additional case. He also provides a letter, inserted, on account of its late arrival, 'at the expense of our advertising columns', which adds to editorial warnings by stressing the serious dangers involved, and noting the type of cases in which caution was especially necessary. He promises to disclose his failures with the method at the first opportunity. Other pioneers of anaesthesia are also mentioned in this issue-Dr. M'Ewan, Charles Nathan, F.R.C.S., and John Belisario, D.D.S. (Crowther, 1947).

The last number of the Journal presents a contribution 'On the Inhalation of the Vapour of Aether', by D. J. Thomas, Physician to the Melbourne Hospital, who on 2 August 1847, performed the first surgical operation under anaesthesia in Victoria. David Thomas, M.R.C.P., L.S.A., a genial, jovial Welshman, was an able surgeon and a leader of the profession in Melbourne. His paper was presented at a meeting of the Port Phillip Medical Association on 7 September 1847. In it Thomas gives praise to the Journal, and agrees with the editor's caution against using ether indiscriminately in every case. He expresses his disagreement with him, however, in his early statement that it would be short-lived, like many other methods. 'I look upon it', Thomas writes, 'as one of the greatest blessings bestowed upon mankind, and instead of being a nine day's wonder, I consider that . . . it will become much more general'. At the end of his notable paper, there follows a brief editorial note, apologising 'to Mr. Thomas for the omission of a large portion of his paper, the cause of which we will explain in a private communication'. This doubtless included advice of the demise of the Journal with this number, of which no mention had yet been made.

The manuscript of this paper by Thomas, now in the Library of the Australian Medical Association in Melbourne, was discovered by Dr. G. T. Howard and printed in full in the Royal Melbourne Hospital Clinical Reports by the editor, Dr. S. O. Cowen (1933). Comparison of this with the Journal version shows that the reports on five patients upon whom Thomas operated under ether, forming more than half of the written text, have been omitted, together with a few other passages. The original title of the paper has consequently been shortened of its terminal words, 'with Cases'. An introduction to this latter-day printing states that the paper was forwarded to the Journal, but that its ephemeral existence ended before publication could occura mistake, since repeated, that is probably due to the extreme rarity of full sets of the publication. It was due to the examination of a bound copy in the Public Library of New South Wales which had belonged to the printer, William Baker, and was consequently assumed to be complete, which led to omission of the last six numbers in its Ferguson Bibliography listing. Dr. Cowen was perhaps misled by the same set.

The title of the defunct publication was adopted by the influential journal of the Medical Society of Victoria, which flourished from 1856 to 1896 . The name was resurrected in Victoria in 1910, in the renaming of the Intercolonial Medical Journal of Australasia (1896-1910) as the Australian Medical Journal (1910-1914). This, in 1914, combined with the Australasian Medical Gazette (1881-1914) to form the existing Medical Journal of Australia.

An earlier Sydney journal, forerunner of the Australian Medical Journal, was 


\section{Some Early Australian Medical Publications}

once (jocularly) classified as the first published medical journal, for the reason that it was edited by a medical practitioner. This was The Satirist, of which eleven numbers of a first volume appeared in 1843. It was edited by Dr. Revel Johnson, a surgeon, who apparently did not practise medicine. The journal was, however, hailed as an obscene publication and the editor prosecuted, together with the printer and publisher. It was said that Dr. Johnson, 'sought to obtain ... a livelihood and celebrity by bringing to the surface that vileness which ought to remain shrouded in the appropriate veil of obscurity'. He was sent to gaol for two years, the publisher and printer for one.

\section{INFORMATION FOR IMMIGRANTS}

Although a few free immigrants arrived in Australia as early as 1793, it was only in the 1830s that the total of free settlers equalled and passed that of the convict population. The increased migration led to the publication of guidebooks and handbooks for migrants, some of which, as Samuel Butler's The Hand-Book for Australian Emigrants . . . (Glasgow, 1839), include useful information on health and climate. However, another Hand-Book for Emigrants ... (London, 1841), by a medical author John Bright, M.R.C.S., 'Resident for Four Years in the Southern Hemisphere', makes scant reference to health.

A pamphlet wholly devoted to the health of settlers, $A$ Guide to the Preservation of Health in South Australia (Adelaide, Robert Thomas), was published in 1841 (though undated), five years after the foundation of the colony. The author was A. Fitzpatrick, M.D., who, according to the title, was late Physician in Chief to the Polish Army, Physician in Chief to the Belgian Foreign Legion, and Surgeon of the French 6th Hussars; and author of $A$ Treatise on the Effects of Riding on Nervous and Chronic Diseases. He is convinced that fewer affections incidental to climate will be found to occur in South Australia than in any other civilized part of the globe, and that these, including consumption, may be avoided. For this he wisely urges avoidance of intemperance, overcrowding in migrant quarters on arrival, unwholesome food, noxious inhalations and poor housing; and care in regard to pure water, personal cleanliness, diet and dress. He laments the occurrence in Adelaide of 'narrow, illbuilt lanes ... chocked up with all manner of filth, excluding the refreshing breezes from the inhabitants'.

\section{THE EARLY AUSTRALIAN HOSPITALS}

The earliest hospital accommodation for free persons, apart from the admission of paupers to government hospitals in the 1840s, was provided by the first Australian charitable organization, the Benevolent Society of New South Wales. This was established for the care of the poor blind, aged and infirm in 1818, as successor to an earlier society of 1813. At the Benevolent Asylum, built in 1820, the Society provided medical and obstetric care with the aid of an honorary medical staff. Its obstetric wards were later (1866) named the Lying-in Hospital of New South Wales. Through its various institutions, including the Royal Hospital for Women, the Benevolent Society still maintains its early functions. Its annual reports have been published from 1819 to the present year. 


\section{Sir Edward Ford}

Another pioneer charity, the Sydney Dispensary, was established in 1826 for the treatment of the poor. Its first report appeared the same year. Patients were treated as outpatients or in their homes by honorary medical officers. In 1845 the South Wing of the General Hospital, the government convict hospital, was made available to the Dispensary, which opened it as a public hospital called the Sydney Infirmary and Dispensary, the latter still performing its district functions. In 1848 the main central building of the convict hospital was added to the Infirmary and the enlarged establishment carried on here till 1881. Its name was then changed to Sydney Hospital, and, the old building demolished, the present hospital rose on the site. Annual reports for its whole chequered career, from 1826 to the present, were published. The first organized medical instruction in this country was established by the Hospital in 1849. This was a course of three years, for medical apprentices, which was recognized by English examining bodies.

The Royal Melbourne Hospital, established as the Melbourne Hospital in 1841, commenced in a small rented cottage in Little Collins Street, and the next year was moved to a two-storied brick house in Bourke Street, loaned by John Pascoe Fawkner. The foundation stone of the 'old' Melbourne Hospital in Lonsdale Street, now occupied by the Queen Victoria Hospital, was laid by Dr. (later Sir) James Palmer, the Mayor of Melbourne, in 1846. Sir James Palmer is notable as the editor of the standard four-volume edition of The Works of John Hunter, F.R.S., which was published in 1835, five years before his arrival in Melbourne. The first published annual report of the Hospital was for the year 1848 (Russell, 1948).

Few examples of other hospital publications prior to 1850 remain. In 1841 there was published Some account of the Adelaide Hospital, with the rules and regulations, dietary and statistics; in 1847 a report of the Hobart Town General Dispensary and Humane Society, founded to help the indigent sick; in 1844 an isolated report of the Bathurst Hospital; and in 1849 a similarly lonely report of the Goulburn District Hospital. The safe-keeping of hospital records and reports has been notoriously inefficient, even in the present century.

\section{THE FORMATIVE YEARS}

These selections from the publications of the early colonial era, from the founding of the colony to the 1840s, are among the scanty productions of our formative years. At the close of this period of settlement and exploration, the previously all-embracing convict system was virtually at an end, the immigration of free settlers increasing, and representative government about to be established. The colonial medical service, which had served the penal settlement from its beginning, was dissolving as transportation ceased, and private practice was firmly established. The forerunners of our present-day hospitals had been founded by citizens' committees for the charitable care of free people. The universities and their medical schools were yet to come. Public libraries were also distant, though some leading Sydney citizens, as early as 1826, had founded the Australian Subscription Library, and in 1846 a band of doctors established the Australian Medical Subscription Library. By this time, also, every large Australian centre of population had its printing presses. The foundations were laid for the bursting growth and development of the next half century. 


\section{Some Early Australian Medical Publications}

\section{REFERENCES}

ANDERson, D., 'John White: Surgeon-General to the First Fleet', Med. J. Aust., 1933, 1, 183.

Bateson, C., The Convict Ships, 1788-1868, Glasgow, Brown \& Ferguson, 1959.

Brown, K. M., Medical Practice in Old Parramatta, Sydney, Angus \& Robertson, 1947.

Brown, K. M., 'Surgeons in exile at Botany Bay', Bull. Post-Grad. Comm. Med., Univ. Syd., $1951,7,1$.

Cleland, J. B., 'The Naturalist in medicine with particular reference to Australia', Med. J. Aust., 1950, 1, 549.

Coppleson, V. M., 'The life and times of Dr. George Bennett', Bull. Post-Grad. Comm. Med., Univ. Syd., 1955, 11, 207.

[COWEN, S. O.], 'The first scientific paper read before a medical society in Victoria', Roy. Melb. Hosp. Clin. Rep., 1933, 4, 67.

Craig, C., 'A medical pamphlet of 1845', Med. J. Aust., 1941, 2, 266.

CROWTHER, W. E. L. H., 'The introduction of surgical anaesthesia in Van Diemen's Land ...', Med. J. Aust., 1947, $2,561$.

Cumpston, J. H. L., The History of Small-pox in Australia, 1788-1908, Melbourne, Govt. Printer, 1914.

FoRD, E., 'Henry Jeanneret and his first Australian book of dentistry', Dent. J. Aust., 1952, 24, 113.

ForD, E., 'Thomas Jamison and the beginning of medical journalism in Australia', Med. $J$. Aust., 1954, 2, 624.

GandeviA, B., 'The contribution of doctors to early Australiana', J. Amer. med. Ass., 1966, 196, 63.

Levine, S., 'Australia's first two dental books', Ann. Aust. Coll. Dent. Surg., 1967, 1, 19.

McIntosh, A. M., 'The Australian Medical Association', Med. J. Aust., 1951, 1, 533.

McIntosh, A. M., 'The life and times of William Bland', Bull. Post-Grad. Comm. Med., Univ. Syd., 1954, 10, 109.

McIntosh, A. M., 'The case of Dr. James Mitchell', Med. J. Aust., 1956, $2,161$.

MacPherson, J., 'Surgeon-General John White and the Surgeons of the First Fleet', Syd. Univ. med. J., 1928, 31, 115.

MacPherson, J., 'Thomas Jamison, M.D., R.N., Surgeon in First Fleet', Syd. Univ. med. J., $1933,27,162$.

OBITUARY, 'William Sherwin', N.S.W. med. Gaz., 1874, 4, 212.

Russell, K. F., 'The Royal Melbourne Hospital and its early surgeons, 1841-1900', Roy. Melb. Hosp. Clin. Rep., 1948, Centenary Vol. 15.

Verso, M. L., 'A medical account of a voyage on a convict vessel', Med. J. Aust., 1950, $1,625$. 